\title{
Pengaruh Dua Musim Tanam Berbeda dan Beberapa Varietas Terhadap Pertumbuhan dan Produktivitas Padi Gogo
}

\section{Effect of Two Different Planting Seasons and Several Varieties on Growth and Productivity of Upland Rice}

\author{
${ }^{1}$ Sution, ${ }^{2}$ Tuti Sugiarti, ${ }^{3}$ Hartono dan ${ }^{4}$ Laurensius Lehar \\ ${ }^{123}$ Balai Pengkajian Teknologi Pertanian (BPTP) Kalimantan Barat. \\ ${ }^{4}$ Politeknik Pertanian Negeri Kupang- NTT \\ Email : laurensiusl@yahoo.co.id
}

\begin{abstract}
ABSTRAK
Penelitian ini bertujuan untuk mendapatkan adaptasi varietas padi gogo pada dua musim tanam yang berbeda. Rancangan penelitian menggunakan Rancangan Acak Kelompok (RAK) yang terdiri dari 6 perlakuan yaitu Tanam Musim Kemarau + varietas Batu Tegi (P1), Tanam Musim Kemarau + varietas Inpago 8 (P2), Tanam Musim Kemarau + varietas Situ Bagendit (P3), Tanam Musim Hujan + varietas Batu Tegi (P4), Tanam Musim Hujan + varietas Inpago 8 (P5), Tanam Musim Hujan + varietas Situ Bagendit (P6), kemudian diulang sebanyak 4 kali. Hasil penelitian menunjukkan bahwa tanama tertinggi pada perlakukan padi gogo ditanam pada musim hujan menggunakan varietas Batu Tegi 124,46 cm. Penanaman padi gogo pada musim hujan mempunyai jumlah gabah isi per malai dan jumlah gabah per malai lebih tinggi dibanding ditanam pada musim kemarau dan berbanding terbalik dengan persentase gabah hampa tertinggi pada musim kemarau. Penanaman padi gogo varietas Inpago 8 dan Situ Bagendit pada dua musim tanam yang berbeda menunjukkan tidak terjadi perbedaan terhadap bobot 1000 butir, namun varietas Batu Tegi pada musim hujan (26,98 g) lebih tinggi dibanding tanam pada musim kemarau (24,88 g). Produktivitas padi gogo nyata dipengaruhi oleh waktu tanam karena berdasarkan hasil pengamatan menunjukan bahwa varietas Batu Tegi $\left(6,20 \mathrm{t} \mathrm{ha}^{-1}\right)$, Inpago 8 (5,87 t ha-1) dan Situ Bagendit (4,66 t ha-1) lebih tinggi pada musim kemarau dibanding ditanam pada musim hujan.
\end{abstract}

Kata Kunci : Padi gogo, varietas, musim tanam, produktivitas.

\begin{abstract}
This study aims to obtain adaptation of upland rice varieties in two different seasons. The design used was a Randomized Block Design (RBD) consisting of 6 treatments namely planting Dry Season + varieties Batu Tegi (P1), planting Dry Season + varieties Inpago 8 (P2), planting Dry Season + varieties Situ Bagendit (P3), Planting Rainy Season + varieties Batu Tegi (P4), Planting Rainy Season + varieties Inpago 8(P5), Planting Rainy Season + varieties Situ Bagendit (P6), then repeated 4 times. The results showed that the highest crops in upland rice treatments were planted in the rainy season using the varieties of Batu Tegi124,46 cm. Planting upland rice during the rainy season has a higher number of filled grains panicle ${ }^{-1}$ and higher number of grain panicle $^{-1}$ than planted in the dry season, but is inversely proportional to the highest percentage of empty grain in the dry season. Planting of upland rice in varieties Inpago 8 and varieties Situ Bagendit in two different planting seasons showed no difference in the weight of 1.000 grains, but the varieties Batu Tegi in the rainy season (26.98 g) was higher than planting in the dry season $(24.88 \mathrm{~g})$. Upland rice productivity is significantly influenced by planting time because based on
\end{abstract}


the results of observations it shows that the varieties of Batu Tegi $\left(6.20 \mathrm{tha}^{-1}\right)$, Inpago 8 (5.87 tha $\left.{ }^{1}\right)$ and Situ Bagendit (4.66 tha $\mathrm{h}^{-1}$ ) higher in the dry season than being planted in the rainy season.

Keywords: Upland rice, varieties, planting season, productivity.

\section{PENDAHULUAN}

Beras berperan peting terhadap sistem ketahanan pangan nasional dan dijadikan sumber ekonomi bagi sebagian besar penduduk Indonesia. Keadaan pangan disuatu Negara dapat menjadi tidak stabil apabila antara kebutuhan dan peyediaan tidak seimbang. Kebutuhan beras semakin meningkat seiring dengan peningkatan laju pertumbuhan penduduk, terjadinya perubahan pola konsumsi dari non beras ke beras serta tingginya tingkat konsumsi beras nasional. Untuk meningkatkan produksi agar kebutuhan pangan tercapai, salah satunya dengan pemanfaatan lahan kering yang merupakan salah satu alternatif potensial untuk dikembangkan. Salah satu upaya peningkatan produksi padi di lahan kering yaitu dengan pengembangan padi gogo karena luas lahan kering di Indonesia mencapai 51,4 juta ha (Guritno, 2011). Pengembangan padi gogo di Kalimantan Barat mempunyai potensi karena terdapat 2.211.632 ha lahan potensial (Wahyunto dan Shofiyati, 2012). Dukungan sumber daya iklim mendukung untuk pengembangan padi gogo di Kalimantan Barat karena merupakan daerah lintang katulistiwa yang mempunyai curah hujan hampir merata sepanjang musim. Curah hujan terendah di Kabupaten Sanggau bulan Juni dan Agustus rata-rata $<200 \mathrm{~mm}$ bulan $^{-1}$, dan tertinggi rata-rata $>300 \mathrm{~mm}$ bulan $^{-1}$. pada bulan November-Desember dan April (Sution, 2016).

Padi gogo di Kalimantan Barat biasanya ditanam pada Musim Hujan dengan cara budidaya yang masih konvensional mulai dari persiapan lahan dengan cara ditebas dan dibakar, penanaman dengan cara tugal, varietas yang digunakan varietas lokal umur 5-7 bulan, tidak dilakukan pemupukan, pengendalian Organisme Penganggu Tanaman (OPT) berdasarkan konsep kearipan lokal, panen menggunakan ketam dan perontokan gabah dengan cara girik mengunakan kaki. Pola budidaya padi gogo atau biasa disebut oleh masyarakat sebagai padi lading, pola ini dilakukan secara terus menerus.

Varietas unggul merupakan salah satu komponen teknologi yang memiliki peran nyata dalam meningkatkan produksi dan kualitas hasil komoditas pertanian. Selama ini varietas unggul telah banyak berperan penting terhadap peningkatan produksi padi nasional (Tarigan et al., 2013). Berdasarkan hasil penelitian terhadap penggunaan varietas unggul mempunyai peran yang sangat penting dalam upaya peningkatan produktivitas padi (Kiswanto dan Adriyani, 2011). Varietas unggul baru padi berpengaruh terhadap perubahan pola pertanian subsisten menjadi komersial, dan produktivitasnya meningkat mencapai tiga kali lipat dibandingkan dengan varietas lokal (Suprihatno dan Dradjat, 2009). Varietas unggul salah satu teknologi berperan penting dalam peningkatan produksi dan mutu hasil pertanian (Yuniarti dan Kurniati, 2015). Diharapkan setiap daerah mempunyai varietas unggulan, karena tidak semua varietas mempunyai daya adaptasi yang baik pada semua lokasi (Yahumri et al., 2015). Penelitian ini bertujuan untuk mendapatkan adaptasi varietas padi gogo yang sesuai pada dua musim yang berbeda.

\section{METODE PENELITIAN}

Penelitian ini dilaksanakan di Dusun Ponti Kayan, Desa Nekan, Kec. Entikong, Kab. Sanggau. Pada bulan April 2017 Februari 2018. Benih yang digunakan adalah Varietas Batu Tegi, Inpago 8 dan Situ Bagendit. Penelitian ini menggunakan Rancangan Acak Kelompok (RAK) yang terdiri 6 perlakuan yaitu Tanam Musim 
Kemarau + varietas Batu Tegi (P1), Tanam Musim Kemarau + varietas Inpago 8 (P2), Tanam Musim Kemarau + varietas Situ Bagendit (P3), Tanam Musim Hujan + varietas Batu Tegi (P4), Tanam Musim Hujan + varietas Inpago 8 (P5), Tanam Musim Hujan + varietas Situ Bagendit (P6), kemudian diulang sebanyak 4 kali. Variabel yang diamati adalah (1) tinggi tanaman $(\mathrm{cm})$, (2) jumlah anakan (anakan), (3) jumlah malai per rumpun (malai), (4) Panjang malai $(\mathrm{cm})$, (5) jumlah gabah isi per malai (bulir), (6) Persentase gabah hampa (\%), (7) jumlah gabah per malai (butir) (8) bobot 1000 butir (g), dan (9) hasil produksi gabah kering panen $\left(\mathrm{t} \mathrm{ha}^{-1}\right)$. Data dianalisis dengan menggunakan uji $\mathrm{F}$ dan apabila menunjukkan perbedaan yang nyata, maka pengujian dilanjutkan dengan BNT tarap 5\%, untuk mengetahui beda pengaruh antar perlakuan.

Perlakuan benih dilakukan dengan menggunakan fungisida untuk pencegahan penyakit blas. Persiapan lahan tanam Musim Kemarau dilakukan dengan cara menebas rumput kemudian dibakar, sedangkan tanam pada musim hujan lahan bekas tanaman sebelumnya disemprot dengan herbisida, setelah rumputnya mati diratakan dan kemudian ditanami. Penanaman dilakukan dengan cara tugal dengan menggunakan jumlah benih 5-7 biji lobang ${ }^{-1}$, penanaman dengan sistem tanam jajar legowo 4:1 $(40 \mathrm{~cm}$ $(20 \mathrm{~cm} \times 10 \mathrm{~cm})$. Pemupukan dilakukan sebanyak 3 kali, pemupukan pertama pada umur 30 hari setelah tugal (hstg) dengan dosis NPK 16:16:16 (60 kg ha-1), Urea (50 kg ha-1), Pemupukan susulan I pada umur $45 \mathrm{hstg}$ dengan pupuk NPK 16:16:16, Urea dan $\mathrm{KCl}$ masing-masing dosis $70 \mathrm{~kg} \mathrm{ha}^{-1}, 35 \mathrm{~kg} \mathrm{ha}^{-1}$ dan $25 \mathrm{~kg} \mathrm{ha}^{-1}$. Pemupukan susulan II pada umur $60 \mathrm{hstg}$, dengan pemupukan NPK 16:16:16, Urea dan $\mathrm{KCl}$ masing-masing dosis $70 \mathrm{~kg} \mathrm{ha}{ }^{-1}, 35 \mathrm{ha}^{-1}$ dan $25 \mathrm{~kg} \mathrm{ha}{ }^{-1}$. Pengendalian gulma dilakukan secara kimiawi dan secara manual dengan mencabut rumput. Pengendalian Organisme Penganggu Tanaman (OPT) dilakukan dengan konsep Pengendalian Hama Terpadu (PHT). Panen dilakukan dengan sabit bergerigi, perontokan gabah dengan cara pampong yaitu dengan cara memukul malai gabah pada bambu yang tersusun agak jarak, sehingga gabah tersebut rontok kebawah.

\section{HASIL DAN PEMBAHASAN}

\section{Komponen Pertumbuhan vegetatif Tanaman}

Hasil analisis ragam terhadap tinggi tanaman padi pada perlakukan tanam pada musim hujan varietas Batu Tegi 124,46 cm berbeda nyata dengan perlakuan tanam musim kemarau varietas Inpago 8, varietas Situ Bagendit tanam musim hujan dan kemarau masing-masing 112,96 cm, 83,04 $\mathrm{cm}$ dan $89,75 \mathrm{~cm}$ (Tabel 1). Tinggi tanaman sangat ditentukan oleh faktor genetik dan faktor lingkungan. Pada Tabel 1 dibawah terlihat bahwa secara genetik varietas Batu Tegi lebih tinggi dibanding varietas yang lainnya. Faktor lingkungan menunjukan bahwa padi gogo yang ditanam pada musim hujan mempunyai pertumbuhan tanaman yang relatif lebih tinggi dibanding padi gogo yang ditanam pada musim kemarau, hal ini disebabkan pada musim hujan tanaman mendapatkan air yang cukup sehingga pertumbuhan lebih maksimal.

Menurut Pratiwi dan

Arisoesilaningsih (2014), bahwa padi merah varietas Aek Sibundong yang ditanam pada dua musim tanam yang berbeda pada kondisi adaptasi berbeda menunjukkan bahwa yang ditanam dekat saluran irigasi mempunyai tinggi maksimal 102-117 cm dibanding ditanam pada bagian tengah sawah dan yang jauh dari irigasi. Menurut Toha et al., (2009), bahwa rata-rata pertumbuhan tinggi tanaman padi maksimum pada beberapa varietas dan ditanam pada waktu yang berbeda menujukkan bahwa padi yang ditanam pada musim hujan lebih tinggi dari pada pertanaman musim kemarau. Tinggi tanaman padi secara langsung tidak berpengaruh terhadap produktivitas tetapi lebih berkaitan dengan panjang malai dan tahan kerebahan. Tinggi tanaman merupakan salah satu kriteria seleksi pada tanaman padi, namun pertumbuhan yang tinggi belum menjamin tingkat produksinya (Suprapto dan Dradjat. 
2009). Perbedaan tinggi tanaman yang dicapai pada dua musim tanam yang berbeda menunjukkan bahwa iklim berpengaruh terhadap parameter pertumbuhan tanaman (Rahman dan Fattah, 2014).

Hasil analisis statistik terhadap jumlah anakan padi gogo pada saat panen menunjukkan bahwa tertinggi pada perlakukan tanam musim hujan varietas Situ Bagendit 13,67 anakan, berpengaruh nyata terhadap perlakuan tanam pada musim hujan varietas Situ Bagendit 10,38 anakan (Tabel 1). Berdasarkan tabel diatas menunjukkan bahwa varietas Situ Bagendit dalam pembentukan anakan sangat dipengaruhi oleh musim, apabila tanaman mendapatkan air yang cukup maka pembentukan anakan akan maksimal. Berbeda dengan varietas Batu Tegi dan Inpago 8 bahwa dengan ketersediaan air yang kurang optimum akan membentuk anakan yang sama pada saat tanaman

Tabel 1. Rata-rata tinggi tanaman dan jumlah anakan pada dua musim tanam berbeda dengan menggunakan beberapa varietas padi gogo.

\begin{tabular}{lrlc}
\hline Perlakuan & \multicolumn{1}{c}{ Tinggi } & Jlh Anakan \\
\hline MK+ Batu Tegi & 118.79 & ab & $10.38 \quad \mathrm{~b}$ \\
MK+Inpago 8 & 112.96 & $\mathrm{~b}$ & $12.17 \mathrm{ab}$ \\
MK+Situ Begendit & 83.04 & $\mathrm{c}$ & $12.71 \quad \mathrm{ab}$ \\
MH+Batu Tegi & 124.46 & $\mathrm{a}$ & $12.29 \mathrm{ab}$ \\
MH+Inpago 8 & 116.97 & $\mathrm{ab}$ & $12.08 \mathrm{ab}$ \\
MH+Situ Bagendit & 89.75 & $\mathrm{c}$ & $13.67 \mathrm{a}$ \\
\hline BNT 5\% & 11.10 & 2.82 \\
\hline
\end{tabular}

Keterangan : Angka didampingi huruf yang sama pada kolom yang sama berarti tidak berbeda nyata menurut uji BNT 5\%.

\section{Komponen Pertumbuhan Generatif Tanaman}

Pada Tabel 2, menunjukkan bahwa pengamatan terhadap panjang malai, jumlah gabah per malai dan jumlah gabah isi per malai mempunyai hasil analisis statistik yang hampir sama yaitu padi gogo tanam pada musim hujan varietas Inpago 8 lebih tinggi dan berbeda nyata dengan varietas Batu Tegi di tanam musim kemarau dan varietas Situ Bagendit ditanam musim hujan. Berdasarkan hasil analisis statistik terhadap panjang malai padi gogo tertinggi pada perlakuan tanam di musim hujan varietas Inpago $8(23,59 \mathrm{~cm})$ berbeda nyata dengan tanam musim hujan mendapatkan air yang cukup. Varietas Aei Sibundong yang ditanam pada dua musim dan tiga lokasi yang berbeda yaitu dekat saluran irigasi, ditengah sawah dan jauh dari irigasi mempunyai jumlah anakan yang tidak berbeda (Pratiwi dan Arisoessilaningsih, 2014). Ditambahkan oleh Makarim dan Suhartatik (2009), bahwa periode utama terjadinya perbanyakan anakan signifikan biasanya pada saat fase vegetatif. Jumlah anakan sangat menentukan jumlah malai dari tanaman, sehingga terdapat korelasi antara jumlah malai dengan hasil, karena makin banyak jumlah malai maka makin tinggi hasil tanaman padi. Anakan produktif per rumpun atau persatuan luas merupakan penentu terhadap jumlah malai dengan demikian anakan produktif merupakan salah satu komponen hasil yang berpengaruh langsung terhadap tinggi rendahnya hasil gabah. 
kemarau varietas Batu Tegi (101,11 butir) dan tanam musim hujan varietas Situ Begendit (108,28 butir). Pada dasarnya padi gogo di Kalimantan Barat dapat ditanam dua kali musim tanam, karena berdasarkan jumlah gabah hampir tidak ada perbedaan tanam antara musim kemarau dan musim hujan, namun karena penanaman di luar musim maka persentase gabah hampa lebih tinggi pada musim kemarau.

Hasil analisis statistik terhadap pengamatan jumlah gabah isi per malai menunjukkan bahwa perlakuan waktu tanam musim hujan dengan menggunakan varietas Inpago 8 mempunyai jumlah gabah isi tertinggi ( 99,35 butir) dan berbeda nyata dengan waktu tanam musim kemerau varietas Batu Tegi (56,04 butir), Inpago 8 (77,80 butir) dan Situ Begendit (30,37 butir) serta waktu tanam musim hujan varietas Situ Bagendit (82,76 butir) disajikan pada Tabel 2. Jumlah butir isi per malai berhubungan nyata dengan hasil tanaman tetapi sangat dipengaruhi oleh gabah hampa. Demikian juga dengan bobot butir gabah isi adalah salah satu penentu terhadap berat hasil. Jumlah gabah isi per malai mempunyai korelasi nyata dengan hasil, sehingga jumlah gabah isi per malai merupakan salah satu acuan kriteria seleksi untuk mendapatkan hasi tinggi (Bobihoe dan Jumakir. 2011). Berdasarkan hasil penelitian Toha et al., (2009) pada beberapa waktu tanam padi terhadap jumlah gabah isi tertinggi pada periode 27 Agustus 2001 dan terendah waktu tanam 12 November 2001.

Tabel 2. Rata-rata panjang malai, jumlah gabah, jumlah gabah isi dan persentase gabah hampa pada dua musim tanam berbeda dengan menggunakan beberapa varietas padi gogo.

\begin{tabular}{|c|c|c|c|c|c|c|c|}
\hline Perlakuan & Panjang malai & Jlh G & bah & $\begin{array}{c}\text { Jlh Gab } \\
\text { isi }\end{array}$ & & $\begin{array}{l}\% \text { gabal } \\
\text { Hampa }\end{array}$ & \\
\hline MK+ Batu Tegi & $21.93 \mathrm{bc}$ & 101.11 & $\mathrm{c}$ & 56.04 & $\mathrm{~d}$ & 44.44 & $\mathrm{a}$ \\
\hline MK+Inpago 8 & $23.12 \mathrm{ab}$ & 114.97 & $\mathrm{ab}$ & 77.80 & $\mathrm{~b}$ & 32.35 & $\mathrm{~b}$ \\
\hline MK+Situ Begendit & $21.83 \mathrm{c}$ & 108.73 & $a b c$ & 75.84 & $\mathrm{~b}$ & 30.37 & $\mathrm{~b}$ \\
\hline MH+Batu Tegi & $22.73 \mathrm{abc}$ & 118.31 & $\mathrm{a}$ & 96.70 & $\mathrm{a}$ & 18.28 & $\mathrm{c}$ \\
\hline MH+Inpago 8 & 23.59 a & 119.73 & $\mathrm{a}$ & 99.35 & $\mathrm{a}$ & 16.92 & $\mathrm{c}$ \\
\hline MH+Situ Bagendit & $22.08 \mathrm{bc}$ & 108.28 & $\mathrm{bc}$ & 82.76 & $\mathrm{~b}$ & 17.84 & $\mathrm{c}$ \\
\hline BNT $5 \%$ & 1.25 & 10.36 & & 9.90 & & 9.14 & \\
\hline
\end{tabular}

Keterangan : Angka didampingi huruf yang sama pada kolom yang sama berarti tidak berbeda nyata menurut uji BNT $5 \%$.

Jumlah gabah hampa hasil analisis menujukan bahwa perlakukan waktu tanam pada musim kemarau varietas Batu Tegi mempunyai persentase gabah hampa yang sangat tinggi $(44,44 \%)$ dan berpengaruh nyata dengan perlakuan waktu tanam musim hujan varietas Batu Tegi (18,28\%), Inpago 8 $(16,92 \%)$ dan Situ Begendit (17,84\%), disajikan pada Tabel 2. Secara umum varietas padi gogo yang ditanam pada musim kemarau mempunyai persentase gabah hampa yang sangat tinggi dibanding waktu tanam musim hujan. Penanaman padi gogo pada musim kemarau dilakukan diluar musim, dimana petani lain tidak tanam dan baru pertama kali dilakukan penanaman di lokasi tersebut.
Salah satu faktor yang meyebabkan terjadinya persentase hama tinggi karena tingginya serangan OPT terutama hama walang sangit, yang mengisap butir malai sehingga gabah tersebut banyak yang hampa. Berdasarkan hasil penelitian yang dilakukan di Kecamatan Balai, Kabupaten Sanggau bahwa produktivitas padi ladang rendah karena disebabkan oleh serangan hama walang sangit (Sution, 2017). Penelitian sebelumnya menunjukan hasil yang hampir sama terhadap persentase gabah hampa bahwa penanaman padi gogo di luar musim dengan perlakuan pemupukan anorganik $150 \%$ persentase gabah hampa mencapai 34,44\% (Sution et al., 2018). Bila dianalisis 
lebih jauh hubungan anatar jumlah gabah isi dan persentase gabah hampa (Tabel 2), mempunyai hubungan yang negatif, artinya semakin tinggi persentase gabah hampa maka jumlah bahan isi semakin sedikit, demikian sebaliknya semakin tinggi jumlah gabah isi, maka semakin rendah persentase gabah hampa.

\section{Komponen Hasil}

Hasil analisis statistic menujukan bahwa jumlah malai per rumpun pada perlakukan waktu tanam musim hujan dengan menggunakan tiga varietas padi gogo Batu Tegi $(11,92 \mathrm{~cm})$, Inpago $8(11,13 \mathrm{~cm})$ dan Situ Begendit $(11,17 \mathrm{~cm})$ mempunyai jumlah malai lebih tinggi dibanding tanam pada musim kemarau dengan varietas yang sama (Tabel 3). Berdasarkan hasil penelitian Toha et al., (2009) pada beberapa waktu tanam padi terhadap jumlah malai tertinggi pada periode 21 Januari 2002 dan terendah waktu tanam 27 September 2001.

Berdasarkan hasil analisis statistik terhadap pengamatan bobot 1.000 butir tertinggi pada perlakuan waktu tanam musim hujan varietas Batu Tegi (26,98 g) berbeda signifikan dengan perlakukan waktu tanam musim kemarau varietas Batu Tegi $(24,88 \mathrm{~g})$ dan varietas Situ Bagendit waktu tanam musim kemarau dan hujan masing-masing $24,24 \mathrm{~g}$ dan 25,32 g. Bobot 1.000 butir secara umum lebih dipengaruhi oleh varietas terlihat varietas Situ Bagendit yang ditanam pada musim kemarau dan musim hujan mempunyai bobot yang sama, demikian pula varietas Inpago 8 waktu tanam tidak berpengaruh terhadap bobot 1.000 butir. Menurut Toha et al., (2009) bahwa bobot 1.000 butir tertinggi waktu tanam pada 12 Oktober 2001, dan terendah pada waktu periode tanam 27 Januari 2002.

Produktivitas padi gogo berdasarkan hasil ubinan $2 \mathrm{~m}$ x $5 \mathrm{~m}=10 \mathrm{~m}^{2}$ menunjukkan bahwa tertinggi pada perlakuan waktu tanam musim hujan varietas Batu Tegi dan Inpago 8 masing-masing $6,20 \mathrm{t} \mathrm{ha}^{-1}$ dan $5,88 \mathrm{t} \mathrm{ha}^{-1}$, yang berbeda nyata dengan perlakuan lainya. Waktu tanam sangat menentukan terhadap produktivitas tanaman, penanaman pada musim hujan menunjukkan bahwa ketiga varietas mempunyai potensi hasil yang cukup tinggi dibanding waktu tanam musim kemarau. Komponen produksi yang sangat berpengaruh yaitu jumlah malai per rumpun dan jumlah gabah isi per malai.

Tabel 3. Rata-rata jumlah malai, bobot 1000 butir dan produksi pada dua musim tanam berbeda dengan menggunakan beberapa varietas padi gogo.

\begin{tabular}{lrlrlcl}
\hline & \multicolumn{7}{c}{ Bobot 1000} \\
Perlakuan & Jlh Malai & butir & Produksi & \\
\hline MK+ Batu Tegi & 6.63 & $\mathrm{~b}$ & 24.88 & $\mathrm{bc}$ & 1,832 & $\mathrm{~d}$ \\
MK+Inpago 8 & 8.17 & $\mathrm{~b}$ & 25.93 & $\mathrm{ab}$ & 3,269 & $\mathrm{c}$ \\
MK+Situ Begendit & 7.67 & $\mathrm{~b}$ & 24.24 & $\mathrm{c}$ & 2,778 & $\mathrm{c}$ \\
MH+Batu Tegi & 11.92 & $\mathrm{a}$ & 26.98 & $\mathrm{a}$ & 6,200 & $\mathrm{a}$ \\
MH+Inpago 8 & 11.13 & $\mathrm{a}$ & 26.50 & $\mathrm{ab}$ & 5,875 & $\mathrm{a}$ \\
MH+Situ Bagendit & 11.17 & $\mathrm{a}$ & 25.32 & $\mathrm{bc}$ & 4,661 & $\mathrm{~b}$ \\
\hline BNT 5\% & 1.76 & 1.65 & & 936.02 & \\
\hline
\end{tabular}

Keterangan : Angka didampingi huruf yang sama pada kolom yang sama berarti tidak berbeda nyata menurut uji BNT 5\%.

Produksi rata-rata gabah padi merah varietas Aek Sibundong yang ditanam musim kemarau 5,26 $\mathrm{t} \mathrm{ha}^{-1}$ sedangkan pada musim hujan terjadi peningkatan sebesar $1,71 \%$, hal ini dipengaruhi karena pada musim tanam kedua ketersediaan air cukup dibanding tanam pada musism pertama ((Pratiwi dan Arisoesilaningsih, 2014). Menurut Toha et al., (2009) bahwa penanaman padi pada musim kemarau sebaiknya pada bulan Juni Agustus, sedangkan penanaman padi pada musim hujan sebaiknya pada bulan Januari - 
Februari. Beberapa hasil penelitian menunjukkan bahwa penanaman padi pada musim hujan lebih tinggi dibanding pada musim kemarau, hal ini disebabkan jumlah gabah isi dan bobot 1.000 butir lebih tinggi pada musim hujan (Satoto et al., 2013). Padi sawah yang ditanam pada dua musim yang berbeda menunjukan bahwa varietas Inpari 7 dan Inpari 13 produksinya signifikan dipengaruhi oleh perubahan iklim, dimana pada musim kemarau varietas inpari $7(6,51 \mathrm{t}$ ha-1) ditanam pada musim hujan terjadi peningkatan $25,20 \%$ demikian juga varietas Inpari 13 pada musim kemarau 7,89 t ha-1 ditanam pada musim hujan meningkat sebesar 18,25\% (Rahman dan Fattah, 2014).

\section{DAFTAR PUSTAKA}

Bobihoe, J. dan Jumakir. 2011. Uji Adaptasi Beberapa Varietas Unggul Baru (VUB) Padi Sawah di Provinsi Jambi. Prosiding Seminar Nasional Pengkajian dan Diseminasi Inovasi Pertanian Menduking Program Strategi Kementrian Pertanian Buku 3, Cisarua 9-11 Desember 2010. Balai Besar Pengkajian dan Pengembangan Teknologi Pertanian. Bogor.

Guritno, B. 2011. Pola Tanam di Lahan Kering. UB press.

Kiswanto dan F.Y. Adriyani. 2011. Uji Adaptasi Varietas Unggul Baru Padi Sawah di Kecamatan Pubiana Lampung Tengah. Prosiding Seminar Nasional Pengkajian dan Diseminasi Inovasi Pertanian Menduking Program Strategi Kementrian Pertanian Buku 2, Cisarua 9-11 Desember 2010. Balai Besar Pengkajian dan Pengembangan Teknologi Pertanian. Bogor.

Makarim, A.K. \& E. Suhartatik. 2009. Morfologi dan Fisiologi Tanaman
Padi. Balai Besar Penelitian Tanaman Padi. 295-329.

Rahman, A., dan A. Fattah. 2014. Kajian Beberapa Varietas Unggul Baru Padi Sawah Pada Musim Hujan dan Musim Kemarau di Sulawesi Selatan. Prosiding Seminar Nasional 2013 Inovasi Teknologi Padi Adaptif Perubahan Iklim Global Mendukung Surplus 10 Juta Ton Beras tahun 2014. Badan Penelitian Dan Pengembangan Pertanian. Kementerian Pertanian. Sukamandi. 643-650.

Satoto, Yuni Widyastuti, Untung Susanto, dan Made J. Mejaya. 2013. Perbedaan Hasil Padi Antarmusim di Lahan Sawah Irigasi. J. Iptek Tanaman Pangan. 8 (2) : 55-61.

Suprihatno, B. dan A.A. Daradjat. 2009. Kemajuan dan Ketersediaan Varietas Unggul Padi Buku 1. Balai Besar Penelitian Tanaman Padi. Sukamandi. 331-352.

Sution.2016. Kajian Pupuk Anorganik Dan Bahan Organik Sebagai Upaya Peningkatan Produksi Padi Gogo (Oryza sativa L.) Varietas Situ Bagendit Pada Agroekosistem Lintang Khatulistiwa. Tesis Program Pascasarjana Fakultas Pertanian Universitas Brawijaya. Malang

Sution. 2017. Teknologi Budidaya Padi Gogo di Kalimantan Barat, Kabupaten Sanggau (Studi Kasus di Kecamatan Balai). J. Agros 19 (1) : 77-87.

Sution., A. Suryanto and M. Santoso. 2018. A study on inorganic fertilizers and organic materials to increase the productivity of rice crop (Oryza sativa L.) in equatorial 
agroecosystems. J. Internasional Journal of Plant Biology 9(1) : 5-8.

Pratiwi, T.A., dan E. Arisoesilaningsih. Variasi Spasial Pertumbuhan dan Produktivitas Padi Merah Akibat Pengairan Berbeda di Sawah Organik Desa Sengguruh, Kecamatan Kepanjen Kabupaten Malang. J. Biotropika 2(2) : 67-72.

Tarigan, E.E., J. Ginting dan Meiriani. 2013. Pertumbuhan dan Produksi Beberapa Varietas Padi Gogo Terhadap Pemberian Pupuk Organik Cair. J. Olline Agroekoteknologi 2(1): 113-120.

Toha, H.M., K. Pirngadi, K. Permadi, dan A.M. Fagi. 2009. Meningkatkan dan Memantapkan Produktivitas dan Produksi Padi Gogo. Padi Inovasi Teknologi Produksi Buku 2. Balai Besar Penelitian Tanaman Padi. Badan Penelitian dan
Pengembangan Pertanian. Sukamandi. 167-199.

Wahyunto dan R. Shofiyati. 2012. Wilayah Potensial Lahan Kering Untuk Mendukung Pemenuhan Kebutuhan Pangan di Indonesia. Badan Litbang Pertanian. Kementerian Pertanian. 297-315.

Yahumri., A. Damiri, Yartiwi dan Afrizon. 2015. Keragaan Pertumbuhan dan Hasil Tiga Varietas Unggul Baru Padi sawah di Kabupaten Seluma, Bengkulu. Jurnal Pro Sem Nas Masy Biodiv Indon. 1(5) : 1217-1221.

Yuniarti, S dan S. Kurniati. 2015. Keragaan Pertumbuhan dan Hasil Varietas Unggul Baru (VUB) Padi Pada Lahan sawah Irigasi di Kabupaten Pandeglang Banten. Pros Sem Nas Masy Biodiv Indon. 1(7) : 16661669. 